\title{
The Image of Polish Women in the Early 1950s
}

\author{
Marta Frączkiewicz
}

\begin{abstract}
Over the past decades, there were questions often asked: What is education? What is it purpose in the world whether it helps an individual or not to understand himself and connect his views with existing beliefs and critical thinking about education to deal with daily practical challenges enable in a new way. The founder of instrumentalism philosophical school, John Dewey remarks that knowledge is practical instrument that purpose must be to solve all problems that a person encounters during his/her lifetime. According to instrumentalism theoretical concepts, theories are instruments by means of that relationship with surrounding world is established (communication becomes possible). Representatives of traditional epistemology make distinct difference between "world" and "mind". In accordance with Dewey's genetic epistemology mind, constitutes the result of living being-environment relationship as the universe is defined by our mind and the development of a human's knowledge is adaptive response to the environment.
\end{abstract}

\section{Keywords}

Polish women, masss media, Polish People's Republic, cultural policy, female work leaders

The main purpose of this paper is to show the situation and image of Polish women in the early 1950s. The author would especially like to present the changes in women's social and professional role, which had its place in discussed period and is also visible in media.

In this paper, the author would like to underline that every change in social, political, cultural, or economical life is visible in the images from the period, when they were made. The basis of this research will provide movies, posters, brochures, magazines, newspapers, archival video footage from the era and literature, both from the period in question, as well as contemporary. To write this paper, the author is also going to compare the image of Polish women to the examples from the United States and Western Europe from discussed period. Her main area of interest will be the ways of writing about women and showing their images in short intervals. She was going to introduce the way of change on the chosen examples.
From the beginning of the First World War and later, during the World War II, a lot of Polish men were involved in warfare. A lot of them left to join the army and partisans, died or went to captivity, because of what the scope of women's responsibilities expanded. Women, who lived in the villages, have had to fulfill the men's responsibilities at farms and take care of their entire families by themselves. Their new responsibilities where not only taking care of animals at the farm or sowing, and gathering the crops. They also had to find the way to earn some money and buy things, which they could not produce on the farms, find and buy firewood and, most importantly, keep the family safe. Women living in Polish towns and cities

\footnotetext{
aNicolaus Copernicus University in Toruń, Poland

Correspondent Author:

Marta Frączkiewicz, Ruś 75, 10-687 Olsztyn, Poland

E-mail: marta-fraczkiewicz@wp.pl
} 
also had to take some new responsibilities when war began. They took over their man's jobs in factories and services not only to provide living for their families, but also to keep whole industry going. A lot of women worked in military industry, which was the main focus at the time (Kościk 2007: 207-208).

Also, we cannot forget about women, who participated in warfare actively. Many women devoted themselves and risked their lives many times while working as couriers, nurses, secret agents, or even partisans. Unfortunately many women, even these, who stayed at homes, also became war victims. They not only had to take care of whole families and risk their lives helping and taking care of soldiers on the front. They also suffered because of the rapes and beatings caused by German and Soviet soldiers. The second ones were so well for their brutal rapes that there was a poster created in the 1940s. Poster presented literally a woman being brutally held and touched by a huge, monstrous, soldier in Russian uniform. There is also a sign on the top of a picture: "Do you want this to happen to girls and women in Warsaw? Defend against Bolsheviks!". They might come to receive some information about where their husbands, sons, or fathers were, to humiliate them or just because they could and there was acquiescence to do such things (Musiał 2012: 36-38).

Because women did not work in many of the professions, which were considered to be typical male occupations, before the war period, they did not have any qualifications. During both wars, a lot of women have been trained to be welders, bricklayers, drivers, and other, less specialized factory workers. The qualifications they gained both in factory work and in maintaining the farms and families lasted and appeared to be useful also after 1945, in the new socialistic reality (Kościk 2007: 208-209).

\section{POLISH PEOPLE'S REPUBLIC}

After the end of World War II, a lot of men did not return to their homes, stayed injured or disabled or stayed abroad because of different reasons. Many war widows and young women, who lost their husbands, fathers, brothers, and fiancés, had to continue their war responsibilities (Podskarbi 2011: 262). The disproportion between the sexes in Poland reached 100 women to only 63 men in 1950. This disproportion means that right after the war was two times more women than men in Poland (Florczyk 2011: 271).

In connection with a large gender disparity, women have become an important reservoir of manpower. Getting job was especially important for women who stayed alone after the war and had to keep family and rebuild destruction. According to Katarzyna Florczyk, over $68 \%$ of women who started working in the postwar period treated it, at least initially, as coercion and declared that if their husbands did earn enough money, they would stopped working professionally and stayed at homes, like before war period. The ways to rebuild post-war destruction and rapid industrialization were two following successive plans: three- and six-year. Although many women began to work at the beginning of the war, six-year plan (1950-1955) aimed to start hiring women in Poland on a massive scale. The plan quickly brought the expected results, because during the first few years after the war, the number of married women admitted to work has tripled (Florczyk 2011: 271).

The most disadvantaged group was young women, who had little chance of getting married. However, the new political system promised to give them a whole new range of possibilities in rebuilding the country after war damage and building a better socialistic future. The authorities kept promising social equality and common access to education and work. Young people staying without any prospects were an ideal group for manipulation and acquisition of new employees, who would quickly become greatly dedicated to the system. It was easy to influence 
young people from villages and small towns in particular, because they had no ideas how the life in the city should look like. When they started to work on construction sites or in factories, they settled for a low-wage workers hotel, because they had no comparison. In addition, they were often alienated from their families which encouraged dependency and trust in the party (Podskarbi 2011: 261-262).

Very large impact on shaping the image of the world of young men and women of this period had then the cultural policy. Indoctrination by media and entertainment gave the opportunity to provide information daily in small doses and create people's outlook almost invisibly. Of course, not everyone was that susceptible to this sort of information, but still with luck of other sources of knowledge and the strong authority of the ruling party most of people did take it seriously (Kłoskowska 2005: 422).

The prevalence of many technical innovations after the war, such as radio and television, facilitated spreading information, which was beneficial to the government. Polish popular culture, due to annexations and two successive wars virtually did not exist, so the authorities had found the ideal conditions for the construction of a completely new quality of socialist realism. The core of new art and culture was to present regular working class people at work. Its main role was to be educative and persuasive propaganda. The figures had to be realistic and plain because the beholder had changed. According to Antonina Kłoskowska, art was one of the main achievements of the socialistic revolution. From that moment, the society was supposed to be egalitarian, which meant the most important class was working class and they were the new art viewers and culture spectators. The art and culture had to be understandable for the "new", working class, citizen and fulfil these aesthetic expectations. Thanks to that great and easy influence of culture and art, it had also gained more money from the government at that time, what gave the authorities possibility to control media, even institutionally (Kłoskowska 2005: 434-436).

Film art, because of its easiness and commonness of easiness of reception (watching is entertaining for everyone, even for people without education or even writing skills; watching movies does not need that much focus and effort as reading for example), had become the main focus of the authorities and considered to be the most important medium and field of art. Already in 1949, a meeting of delegates was held in a town Wisla. One of the main announcements of the congress was a manifesto of development of film art, as the most important and most influential of the arts. From that time, movies were to be as "realistic" as it could possibly be. The term "realistic" was meant to mean not what was visible at the moment, but what was reality going to look like in the near future, according to the plan, clearly. The characters since then were constituted to be role models for the viewer and encourage them to devote themselves to hard work (Podskarbi 2011: 262-263).

Many of these films related directly to women, who were big and important labor force in the postwar period. Two, most influential examples of such movies certainly are Przygoda na Marieniensztacie (The Adventure at Mariensztat) from 1953, and Autobus odjeżdza 0 6.20 (The Bus Leaves at 6.20) from 1954. The main character of the first film is Hanka Ruczajówna (acted by Lidia Korsakówna), who decides to leave her home in village and move to Warsaw, where she learns bricklaying and works on the reconstruction of the capital like a man. The plot of second movie is quite similar. There is a girl, named Krystyna (created by Aleksandra Śląska), who decides to leave her unfaithful husband and move from a little to Silesia, where she started working as a welder in ironworks workplace. There is also a film called Irena do domu (Go home Irena), where the main character, a woman named Irena, works as a taxi driver (Podskarbi 2011: 263-264). 
These mentioned titles are only a few examples of whole range of films mentioned to be taken "as an inspiration and teaching for new women". All of them have similar plot. Most of main female characters leave their villages and little towns in the beginning and move to big cities to get requested qualifications and work ad builders (reconstructing damaged by warfare capital) or working in factories. Most of work in occupations, which were considered to be typical male, like builders, welders, or drivers, what brings them many difficulties and disappointment at the beginning. Nevertheless, thanks to their hard work, perseverance and thanks to the benevolent colleagues from work and party that appreciates the effort like no one before, they always get the reward in the end, which is love (of course), appreciation at work and maybe even own two-bedroom flat in block. The main feature of these movies is that they give "hope" to everyone. The films show that everyone, who would work hard, would get the reward, no matter where she comes from and what her qualifications in the beginning are, she can always learn how to build a wall and become the best in it (Podskarbi 2011: 263-265).

We can easily say that socialist film set a new archetype of Polish women. The "new woman" was a workwoman. She could work as hard and as effective as men and occupy the same job position. They also could be feminine and flirtatious after hours, like Hanka Ruczajówna from Przygoda na Mariensztacie. At work, they also often endured colored handkerchiefs, fine jeweler and, in certain professions simple dresses. Most of the characters gained strength and confidence after moving to cities and starting a "rewarding" and "fulfilling" work. Naturally, the problem of motherhood still remains to solve. The mass culture also gives us some, more or less adequate, answer to that problem. Many mass culture characters had children and worked full time, what is clearly impossible to realize without any help. The main source of help was supposed to come from the system. There were a lot of easy opportunities to leave children during work hours, which would provide care, education and food, when their mothers would follow their career dreams, such as nurseries, kindergartens, schools, boarding schools, or canteens. Parents could also eat in canteen during their work hours, thanks to what the mother did not have to cook dinners at home at all during the work week. Living in a workers' hotel was also an option. In this case, retired mother or mother in low was an institution, who had to raise a child in the time, when mother was working (Florczyk 2011: 271-272).

What about fathers then? Unfortunately, in popular culture of the period, fathers were practically not remembered by. At that moment, another archetype came to a life, "the mother polka", which used to work full time, than take her children home from school and kindergarten and work "second shift" at home. Children were at school only during the day, when their mother was also at work. There still were a lot of duties to perform at home, such as laundry, ironing, cleaning, doing homework or shopping, which was the hardest one at that time. Because of lack of goods and their regulation (nutritional cards since 1952), many women had to strive to capture the necessary goods (Podskarbi 2011: 263-265).

A great example of attitude to women in early 1950s are Polish Newsreels, which cover the period from 1944 to 1994. Their goal was the perpetuation and to show everyday life in Poland. Their rhetoric is rather ironic but also moralizing. They show binary examples of reprehensible or, conversely, worthy of imitation behavior. The lector often uses evaluative words like dirty, spoiled or rotten, greedy and vile to determine the condemned behavior and conversely of course. In films showing women at work, especially hard even typical male work, we can see only smiling faces, polite behavior and such words as: beautiful, capable, industrious, persevering, exemplary. In the other hand, when the newsreel is about the fashion 
coming from the West and bought on the free market or other luxuries, for example, we can hear such worlds as: vain, the class enemy or the speculator. Except visual culture, there are also a lot of examples of radio auditions, poems, songs, and other manifestations of oral culture. Like newsreels, they have mostly moralizing and educative function. The most popular was band radio in the radio program one, which was addressed to the women working at home. It gave useful advices, how to take care of husbands and children and improve their home cleaning skills. They also, like films, magazines, or Polish Newsreels, give a lot of examples of working women role models and agitated women to work, by giving information how to start working and where to get some basic work training (Wojciechowski 2007: 216-218).

Press was also very important source of role models and inspiration. Unfortunately, like other media, it became centralized and went under government control. To give an example, before World War II, there was 192 titles of newspapers, after war (in 1961), the amount dropped to only 53. The most popular magazine dedicated to women was Przyjaciótka (The Friend), which began to appear in March 1948. Discussed magazine appeared every week (after 2009 every two weeks) in circulation of more than two million copies and had special allowance for rural women. Even covers of the magazine are interesting already. Especially during the first years of the issue of the magazine, the covers present women with attributes connected to work or some not very feminine activities, like sports. On the cover of the very first edition, we can see a woman with her hair combed in two braids, wearing white shirt with collar, a black jacket. She is smiling and holding the buds of trees. On the covers of next numbers from these year (1948), we can see the women keeping up the mowed cereal, sewing, holding a hen in her hands, voting, throwing a ball in an athletic outfit or just looking forward and smiling dressed in white collar shirt and a tie, with pinned up hair. Most of the pictures, not only the cover ones, present the image of strong, independent women, who had often dressed like men or did traditional male occupations, like voting, with smiles on their faces (Kloskowska 2005: 424).

Inside woman magazines, there is a lot of usual content, like food recipes, advices, and letters from readers or fashion advices. There are also a lot of articles and interviews presenting the attitude of women workers. The readers were meant to identify themselves with the women they were reading about, cheer up and get some encouragement to further work. The titles usually were like "Strong Woman Always Rules" (Vol. 14, 1948) or "Women Are Building the Future" (Vol. 38, 1948). Of course, the characters presented in the paper are also complaining about their jobs and underestimation by men at work, but still such publications helped women to feel that they are not only ones, who have this type of problems that they constitute a group which, gathered together, will survive difficulties and will receive a prize, respect, and admiration (Florczyk 2011: 272-274).

Another example of the spreading the archetype of the New Socialist Women are art and posters. Social realist art was supposed to be the most realistic and show the everyday events of ordinary people, the best at work. The most popular examples of working women monuments from early 1950s are the Bricklayer Woman from the town Tychy in Silesia region, which is handling construction tools in one hand and the little model of a building in the other one, and the Kolkhoz Woman, which is "sitting" in front of the Palace of Culture and Science in Warsaw with the sheaf of harvest in her right hand.

A very important place in the popular culture of the period occupies also propaganda posters, which nowadays have become almost iconic symbol of a bygone era. The most recognized poster is so-called "girls on tractors" from 1951, which presents a young, 
smiling woman driving a tractor and wearing the Union of Polish Youth uniform, which was a khaki skirt, khaki collar shirt, a red tie and nice blond curls on her head. The actual sign was: "Youth go forward to fight for a happy Polish socialist countryside". The role model for the poster was an actual woman named Magdalena Figur, who worked as a tractor driver in that time. Another famous poster is woman holding a trowel and looking forward dressed in a blue dress. The sign says: "We salute to women working for peace and development of the homeland" from 1953. There was also a poster presenting a woman holding construction plans and dressed in blue collar shirt with a white uniform on it, with some construction site in the background. The sign says: "Women in Polish Folk Republic have all equal rights with men in all areas of public, political, economic, social and cultural development. From the article 66 of the project constitution of Polish Folk Republic" (1951). Obviously, these are only few examples of whole range of different posters presenting women from late 1940s and early 1950s. There are also many examples of women working with the harvest or in the shops, canteen kitchens, and factories. What is universal for them is that they all presented women at hard work with smile on their faces. The convention was always the same, suppressed, yellowish colors, working environment and slogan referring to socialistic values.

\section{CONCLUSIONS}

We can say that regardless of the medium, whether it was on television, in the movies, newspapers, or radio, we can describe a basic picture of Polish women, which was imposed and distributed arbitrarily by the cultural policy of the beginning of the Polish People's Republic. According to this image, women were considered to be strong, often performing male occupations, such as a welder and a bricklayer, being able to work as hard as men, and achieve comparable results to them. Stories of women presented in the press, television, and radio often duplicated scenario of leaving life in the countryside or in a small town. Check in to the big city to work in the factory was seen as an opportunity to gain a kind of reward that was inescapable social advancement, career prospects and to find valuable companion. Working class women living in the early 1950 s also had children to take care of. According to mass media, also in this case could rely on state aid. There were institutions aimed at keeping and feeding their offspring at a time when the woman was at work, such as schools, kindergartens, nurseries, and canteens. Nevertheless, returning from a shift in the factory, on a construction site or other workplace, women still had to pick up the kids and provide them care, meals, help with homework, mend clothes or bathe in the afternoon. The role of the man, referring to the media of the era, it was not helping at home. Their duties were to end up just after work for a well-deserved rest at home. A woman, who works hard during the day and after hours, without complaining and even with a smile on her face, takes care of the children and her husband, provides food, and runs the household completely by herself and without complaining is known as an archetype of "Polish Mother". Her heavy and totally independent work at home after returning from work in the factory, for example, sociologists call "second shift".

Of course, the appearance of women never stays irrelevant. At a time, when the Western world was fascinated by globed dresses (in 1950s' style), which iconic already, hairspray and beautiful kitchen appliances, in socialist countries appreciated modesty and simplicity. Outfit had to be egalitarian and fit to work in a factory. Low availability of goods in the socialist world only helped to maintain the appearance suitable for the workers. Female gazing at us from magazines, films or posters mostly have hair worn in a braid, headscarves and uniform: apron of a cook, frock of an architect, Polish Youth Union uniform, possibly 
a simple dress and rolled up sleeves. If women are shown for example at work in the office, then they usually wear a white shirt and suit. There are also quite common images of women in folk costumes, most often by the side of the man. In the press can also be seen photos of female athletes, such as on the covers of the magazine Friend, published since 1948 and until now. The most common sports are generally considered to be typically male disciplines, such as shot put or football. Apartments, in which the women of this period were shown in sample films are also different from modern and colorful apartments of American housewives houses. They were modest and, as well as costumes, keep up with the idea of building a socialist society, the working-class, where everyone has equally, which means almost nothing.

It is commonly believed that there was no second wave of feminism in Poland. When the rich residents of the United States and Western Europe fought for the right to go out from the beautiful and full of modern equipment houses and go to work, in socialist countries, women's labor was widespread. Unfortunately, when we look closely at gender equality in Poland during discussed period, we find that it was only apparent. Women very rarely exercised leadership positions. Most often they worked only as unskilled workers. Showing images of happy, satisfied, and professionally developing women was a convenient move for the authority, because they needed to gain the source to build a new after war reality. Propaganda is the best way to manipulate people. Young women, who did not have any qualifications before and came alone from the countryside very often, were an ideal beholder of cultural politics, which received systematically quickly, begins to be true. There was, of course some reward system existing in the Polish People's Republic period, but it was also fake. The award for production of $200 \%$ of normal task, there was, both for women and men, only a medal and praise from supervisor to gain.

\section{References}

Akuła, S. 2007. "Kobieta z podoławskiej wsi PRL-u" (The Woman From the Village Near Oława in Polish People's Republic). Pp. 224-232 in Gospodarka i spoleczeństwo w czasach PRL-u (1944-1989) [Economy and Society in the Times of Polish People's Republic (1944-1989)]. Warszawa: Gajt Publishing House.

De Beauvoir, S. 2003. Druga pleć (The Second Sex). Warszawa: The Blach Sheep Publishing House.

Domański, H. 1992. Zadowolony niewolnik?: studium Nierówności między mężczyznami i kobietami $w$ Polsce (Satisfied Slave?: Study of Inequalities Between Men and Women in Poland). Warszawa: Publication of the Institute of Philosophy and Sociology PAN.

Florczyk, K. 2011. "Kobiety w 'nowych zawodach' w stalinowskiej Polsce-zarys problematyki" (Women in "New Jobs" in Stalinist Poland-Outline Issues). Pp. 271-274 in Spoleczeństwa PRL (The Society of Polish People's Republic). Vol. 1. Poznań: UAM Scientific Publishing.

Friedman, B. 2012. Mistyka kobiecości (The Feminine). Warszawa: The Blach Sheep Publishing House.

Kłoskowska, A. 2005. Kultura masowa. Krytyka i obrona (Mass Culture. Criticism and Defense). Warszawa: PWN Scientific Publishing.

Kościk, E. 2007. "Kobieta w Rzeczypospolitej Ludowej ma równe z mężczyzną prawa... " (A Woman in the People's Republic Has Equal Rights With the Man... ). Pp. 207-215 in Gospodarka $i$ spoleczeństwo $w$ czasach PRL-u (1944-1989) [Economy and Society in the Times of Polish People's Republic (1944-1989)]. Warszawa: Gajt Publishing House.

Musiał, B. 2012. Wojna Stalina. 1939-1945. Terror, grabież, demontaze (Stalin's War 1939-1945. Terror, Pillage). Poznań: Zysk and S-ka Publishing House.

Pełczyński, G. 2002. Tenth Muse in the Folk Costume: The Image of Peasant Culture in Communist Poland. Poznan: UAM Scientific Publishing.

Podskarbi, R. 2011. "Praca daje wyzwolenie. Nowa kobieta w Nowej Polsce" (Work Gives Liberation. The New Woman in the New Poland). Pp. 261-269 in Spoleczeństwa PRL (The Society of Polish People's Republic). Vol. 1. Poznań: UAM Scientific Publishing.

Skotarczak, D. 2004. Obraz spoleczeństwa PRL w komedii filmowej (Image Communist Society in the Comedy Film). Poznań: Adam Mickiewicz University Publishing House.

Wojciechowski, E. 2007. “'Głos maja kobiety...'-radiowy obraz kobiety polskiej" ("The Voice Belongs to 
Women..."-Radio Image of Polish Women). Pp. 216-223

in Gospodarka $i$ spoleczeństwo $w$ czasach PRL-u (1944-1989) [Economy and Society in the Times of Polish People's Republic (1944-1989)]. Warszawa: Gajt Publishing House.

Wódz, K. 1997. Kobiety wobec przemian okresu transformacji (The Women Towards the Transformation Period). Katowice: Śląsk Publishing House.

\section{Bio}

Marta Frączkiewicz, Ph.D. candidate, teacher, Department of Ethnology and Cultural Anthropology, Nicolaus Copernicus University in Torun, Poland, also works in the National Museum in Gdansk; research fields: Polish "Recovered Territories" in the postwar period, history of East Prussia, the situation of women during the war and postwar, popular culture in communist Poland, gender, and museology. 